\title{
Dairy Beef Production from Mixtures of Sugarcane Bagasse and Concentrates
}

\author{
Paul F. Randel ${ }^{1}$ \\ INTRODUCTION
}

The suitability of sugarcane bagasse for use in feeding beef cattle has long been a subject of interest in cane-growing countries. Kirk et al. (4) ${ }^{2}$ reviewed a number of reports in the literature, most of which indicated that bagasse is inferior to other common roughages in beef cattle rations. However, in a series of experiments extending over 8 years, the abovementioned investigators obtained good results with several bagasse products including whole bagasse, bagasse pith, "Camola" (4 parts bagasse pith and 10 parts cane molasses), and chicken litter bagasse. In feeding periods of from 109 to 144 days duration, balanced rations containing from 20 to 30 percent of these bagasse products resulted in rapid and economical gains during the first $\mathbf{7 0}$ days. Thereafter, however, the rate of gain tended to decline. Complete mixed rations containing 20-percent chicken litter bagasse, ground and sieved through a 1/2-inch screen promoted average daily gains of 2.66 and 2.42 pounds when cottonseed meal and a mixture of cottonseed meal and urea served as the protein supplement, respectively.

Beames (2) tested bagomolasses, a mixture of 30-percent bagasse and 70percent molasses, in rations for 2-year old Hereford steers during a 17week feeding period. Two rations containing 70-percent bagomolasses (equivalent to 21-percent bagasse and 49-percent molasses) and 13.5- or 9.4-percent crude protein resulted in average daily gains of 1.4 and 1.5 pounds, respectively. Another ration containing 50-percent bagomolasses (equivalent to 15-percent bagasse and 35-percent molasses) proved superior, yielding an average daily gain of 2.3 pounds.

The variability of the results obtained when bagasse is fed to beef cattle may be due to differences in the nature of the bagasse employed as well as to the characteristics of the rest of the ration.

The present experiment was conducted to determine how rations containing 20 or 30 percent of finely ground bagasse mixed with molasses

3 Animal Nutritionist, University of Puerto Rico, Mayagũez Campus, Agricultural Experiment Station, Lajas Substation, Lajas, P.R. The author is grateful for help rendered by the Central Analytical Laboratory, Rfo Piedras, in conducting the chemical analyses of feed samples, by Mr. Edgardo Prieto Rodríguez in determining the shear force of meat samples, and by Dr. Gilberto Rosado Carbó in making postmortem examinations of digestive tracts.

2 Italic numbers in parentheses refer to Literature Cited p. 246. 
and other concentrates would promote beef production. Male calves of dairy, breeds were used because these represent the bulk of the presently available cattle which, if economical rations were developed, could be raised for beef production in Puerto Rico.

\section{EXPERIMENTAL METHODS}

Eleven Holstein and 5 Brown Swiss male calves from the Lajas Substation herd were used in the experiment; seven were castrates and nine were intact. All were weaned from milk replacer at a maximum age of 2 months, and thereafter were fed concentrates at a level not exceeding 5 pounds daily, with green forage or silage available ad libitum. Available animals were started in the experiment over an 11-month period from September, 1966 to August, 1967. The starting age ranged from 212 to 278 days, with a mean of 235; the starting liveweights ranged from 162 to 339 pounds, with a mean of 269 .

Housing consisted of an open shed with corrugated sheet metal roof and sloped concrete floor, elevated above ground level. The shed was divided by wooden partitions into eight pens each measuring $15 \times 11$ feet. Each pen was equipped with a manger and an automatic water cup, and accommodated two animals.

The formulas of the four experimental rations, mixtures of partiallydepithed sugarcane bagasse and concentrates, are presented in table 1. Four animals consumed each mixture, offered free choice as the sole diet throughout the experiment. The four formulas represent the treatments of a $2 \times 2$ factorial experimental design, the two factors being bagasse and crude protein. Diets A and B had 20-percent and diets C and D 30-percent bagasse, whereas diets $A$ and $C$ had about 12.5-percent crude protein and diets B and D 16-percent.

Pairs of calves, matched only in age, were randomly assigned to the experimental treatments. A minimal adjustment period of 1 week was allowed each pair of calves before starting the experiment. Green chopped forage and small amounts of concentrates were fed during this preliminary period.

The experimental feeding period extended from 216 to 365 days in individual animals, with a mean duration of 298 . Liveweights were determined on the first day of the experiment and at consecutive monthly intervals. Final individual weights ranged from 970 to 1059 pounds, with a mean of 994. Overnight fasting prior to each scheduled monthly weighing was not practiced during the feeding period; however, feed and water were withheld for a full 24 hours before slaughter.

At slaughter the animals were stunned, then bled from the jugular vein. The quartered carcasses were chilled at approximately $34^{\circ} \mathrm{F}$. temperature 
and 94 percent relative humidity for 24 hours. The four most desirable wholesale cuts (viz, the chuck without neck, fore shank, or brisket; the rib without navel end; the round without hind shank; and the loin without flank) were separated by standard procedures (1). Samples of top round and rib were taken for the Warner-Bratzler shear-force determination as described by Sharrah et al. (7).

The data were subjected to analysis of variance. Orthogonal treatment

TABLE 1.-Formulas and proximate analyses of the experimiental rations

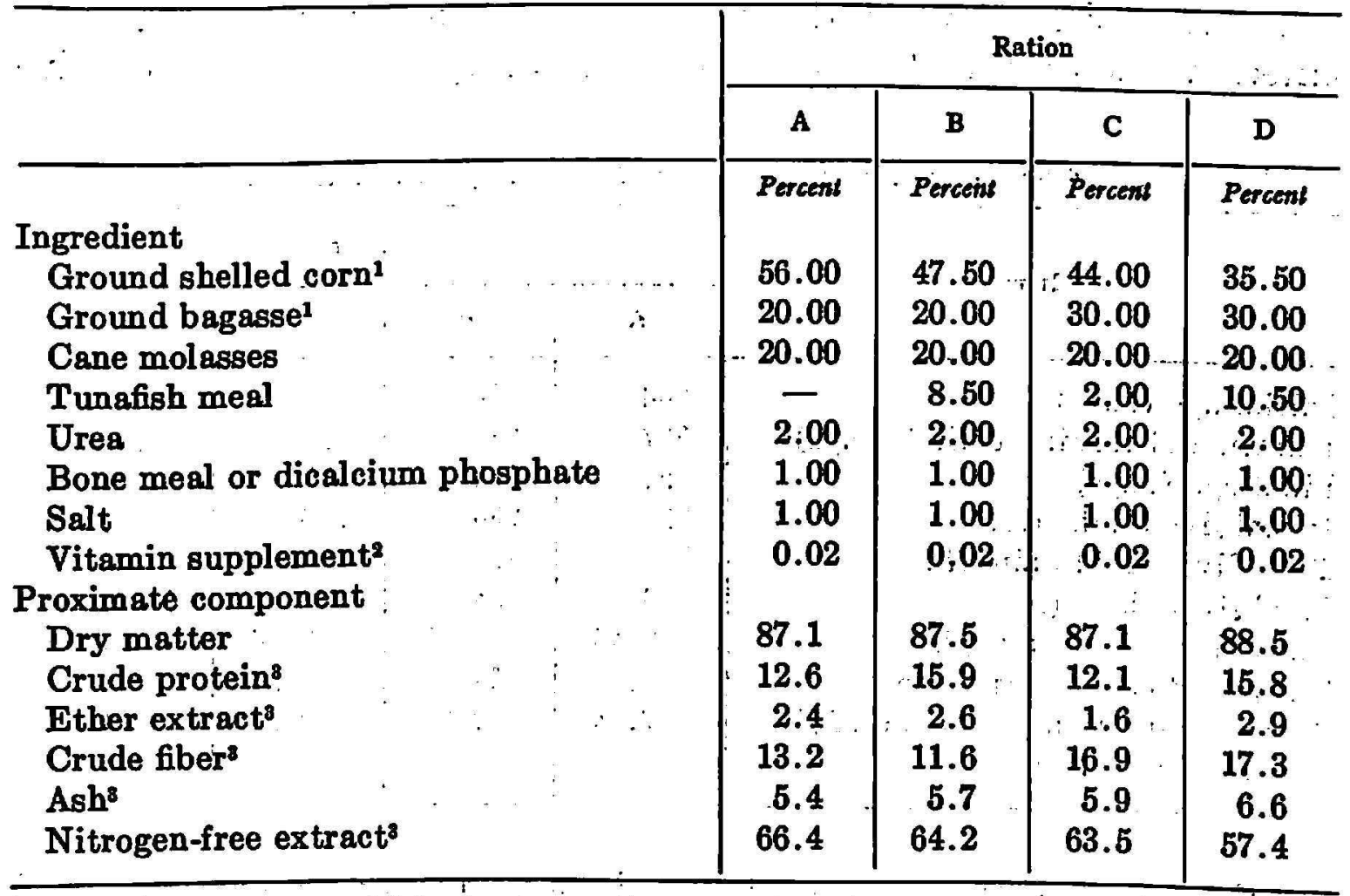

1 Ground to pass a $1 / 4$-inch screen.

2 Generously supplied by Dawe's Laboratories, Chicago, Ill., and containing $3,000,000$ USP units of vitamin $A, 200,000$ IUC units of vitamin $D_{i}$, and $10,000 \mathrm{IU}$ of vitamin $\mathbf{E}$ per pound.

an a dry matter basis.

comparisons were made to test the effects of the level of bagasse, the level of crude protein, and their interaction.

\section{RESULTS AND DISCUSSION}

The average total liveweight gains over the whole experimental feeding period varied from 719 pounds for the animals on ration, $C$ to 757 pounds for those on ration $A$; the average final liveweights ranged from 984 pounds for ration $B$ to 1,002 pounds for ration $D$ (table 2). Daily liveweight gains averaged 2.46, 2.61, 2.54, and 2.33 pounds on rations $A$ through $D$, re- 
spectively (table 2). The treatments had no significant effects on daily growth response.

The average daily feed consumptions varied from 19.0 to 20.5 pounds (table 2). The treatments did not significantly influence feed intake. On diets $C$ and $D$ (30 percent bagasse) the animals consumed 8.07 and 8.45 pounds of feed per pound of liveweight gain, while those on rations $A$ and B (20-percent bagasse) consumed 7.84 and 7.28 pounds, respectively. The trend toward lower feed conversion efficiency at the higher bagasse level was not significant, however.

The marked effect which the stage of growth exerted on these response criteria is shown in table 3, where the average figures for each successive

TABLs 2.-Average growth, feed consumption, and feed conversion responses

\begin{tabular}{l|c|c|c|c}
\hline \multicolumn{1}{c|}{ Item } & \multicolumn{4}{c}{ Ration } \\
\cline { 2 - 5 } & A & B & C & D \\
\hline Initial age (days) & 244 & 234 & 244 & 217 \\
Duration of feeding period (days) & 307 & 287 & 283 & 315 \\
Final age (days) & 551 & 521 & 527 & 532 \\
Initial liveweight (lb.) & 239 & 234 & 276 & 269 \\
Total liveweight gain (lb.) & 757 & 750 & 719 & 733 \\
Final liveweight (lb.) & 996 & 984 & 995 & 1,002 \\
Daily liveweight gain (lb.) & 2.46 & 2.61 & 2.54 & 2.33 \\
Daily feed consumption (lb.) & 19.3 & 19.0 & 20.5 & 19.7 \\
Feed consumption per pound of live- & 7.84 & 7.28 & 8.07 & 8.45 \\
weight gain (lb.) & & & & \\
\hline
\end{tabular}

month of the experiment are presented. Since the first animals reached slaughter weight during the 8th month, the partial data from this and all succeeding months are combined in the table. Average daily feed consumptions increased rapidly at first in all four groups, but tended to level off after about the 4th month on ration $D$, after the 5th month on ration $C$, and after the 6th month on rations $B$ and $A$. When feed intake is expressed per 100 pounds of liveweight to the exponent 0.75 , corresponding to assumed metabolic body size ( $\bar{b})$, rather constant averages are obtained over the first 5 or 6 months (table 3). Thereafter feed consumption per unit of metabolic body size declined. Thus in the final months an exponent lower than 0.75 would be required to better relate liveweight to feed intake.

Average daily liveweight gains maintained a vigorous tempo throughout the first 7 months, declining somewhat thereafter (table 3). The average feed conversion ratios, initially in the range of 4.5 to 5.5 pounds of feed 
TABLE 3.-Average feed consumption, liveweight gain, and feed conversion during successive months on the experiment (all in pounds)

\begin{tabular}{l|l|l|l|l|l|l|l|l|l|l}
\hline \multirow{3}{*}{ Diet } & \multicolumn{10}{|c}{ Month } \\
\cline { 2 - 8 } & 1 & 2 & 3 & 4 & 5 & 6 & 7 & 88 \\
\hline
\end{tabular}

Daily feed consumption per animal

\begin{tabular}{l|l|l|l|l|l|l|l|l}
\hline A & 11.0 & 13.2 & 15.4 & 17.8 & 19.7 & 23.3 & 21.7 & 23.5 \\
B & 11.9 & 12.5 & 15.1 & 18.2 & 19.1 & 21.7 & 22.3 & 24.2 \\
C & 12.5 & 14.6 & 16.6 & 19.7 & 23.0 & 22.6 & 23.4 & 25.1 \\
D & 11.9 & 15.5 & 19.1 & 20.2 & 19.7 & 20.2 & 21.5 & 22.7 \\
\hline
\end{tabular}

Daily feed consumption per 100 pounds metabolic size?

\begin{tabular}{l|l|l|l|l|l|l|l|l}
\hline A & 16.2 & 16.4 & 16.4 & 16.5 & 16.2 & 17.4 & 14.9 & 14.5 \\
B & 18.0 & 16.0 & 16.5 & 17.1 & 15.8 & 16.3 & 15.3 & 15.1 \\
C & 16.9 & 16.8 & 16.6 & 17.4 & 18.1 & 16.1 & 15.4 & 15.3 \\
D & 16.2 & 17.7 & 18.9 & 17.5 & 15.5 & 14.7 & 14.6 & 13.8 \\
\hline
\end{tabular}

Daily liveweight gain

\begin{tabular}{l|l|l|l|l|l|l|l|l}
\hline A & 2.46 & 2.23 & 3.02 & 2.75 & 2.90 & 2.76 & 2.76 & 1.94 \\
B & 2.17 & 2.19 & 2.92 & 3.42 & 2.60 & 2.92 & 2.59 & 2.42 \\
C & 2.34 & 2.71 & 2.50 & 2.87 & 3.26 & 2.90 & 2.30 & 2.08 \\
D & 2.44 & 2.70 & 2.84 & 3.15 & 2.01 & 2.35 & 2.14 & 1.92 \\
\hline
\end{tabular}

Feed consumed per pound of liveweight gain

\begin{tabular}{l|r|r|r|r|r|r|r|r}
\hline A & 4.48 & $\mathbf{5 . 9 0}$ & $\mathbf{5 . 0 9}$ & $\mathbf{6 . 4 6}$ & $\mathbf{6 . 7 9}$ & $\mathbf{8 . 4 5}$ & $\mathbf{7 . 8 8}$ & $\mathbf{1 2 . 1 0}$ \\
$\mathrm{B}$ & $\mathbf{5 . 5 1}$ & $\mathbf{5 . 6 9}$ & $\mathbf{5 . 1 7}$ & $\mathbf{5 . 3 2}$ & $\mathbf{7 . 3 4}$ & $\mathbf{7 . 4 6}$ & $\mathbf{8 . 6 3}$ & $\mathbf{9 . 9 7}$ \\
$\mathrm{C}$ & $\mathbf{5 . 3 3}$ & $\mathbf{5 . 3 8}$ & $\mathbf{6 . 6 3}$ & $\mathbf{6 . 8 7}$ & $\mathbf{7 . 0 5}$ & $\mathbf{7 . 7 9}$ & $\mathbf{1 0 . 1 6}$ & $\mathbf{1 2 . 0 7}$ \\
$\mathrm{D}$ & 4.89 & $\mathbf{5 . 7 3}$ & $\mathbf{6 . 7 2}$ & $\mathbf{6 . 4 1}$ & $\mathbf{9 . 8 1}$ & $\mathbf{8 . 5 9}$ & $\mathbf{1 0 . 0 7}$ & $\mathbf{1 1 . 9 8}$ \\
\hline
\end{tabular}

1 Partial data from the 8th and all subsequent months.

2 Assumed to be liveweight to the exponent 0.75 .

per pound of liveweight gain, tended to increase steadily with time (table 3). Ratios in excess of 10 were eventually reached on all except ration $B$, where the maximum 9.97 was borderline. In general, the feed conversion ratios at different stages were comparable to those listed by the National Research Council for good quality feeder calves fattened from 400 to 1,000 pounds, ranging from 5.2 to 10.0 (6) with increasing age of the calf.

During the 24-hour shrink prior to slaughter, the animals on rations A through D lost 3.10, 3.35, 5.13, and 5.09 percent of their final fed liveweight, respectively (table 4$)$. A highly significant $(P<.01)$ difference in shrink 
percentage was found upon comparing the combined average of rations $A$ and $B$ with that of rations $C$ and $D$. Logically the animals consuming the latter rations with the higher percentage of bagasse would have more indigestible food residues in their digestive tracts at the start of fasting,

TABLE 4.-Average shrink losses and carcass data

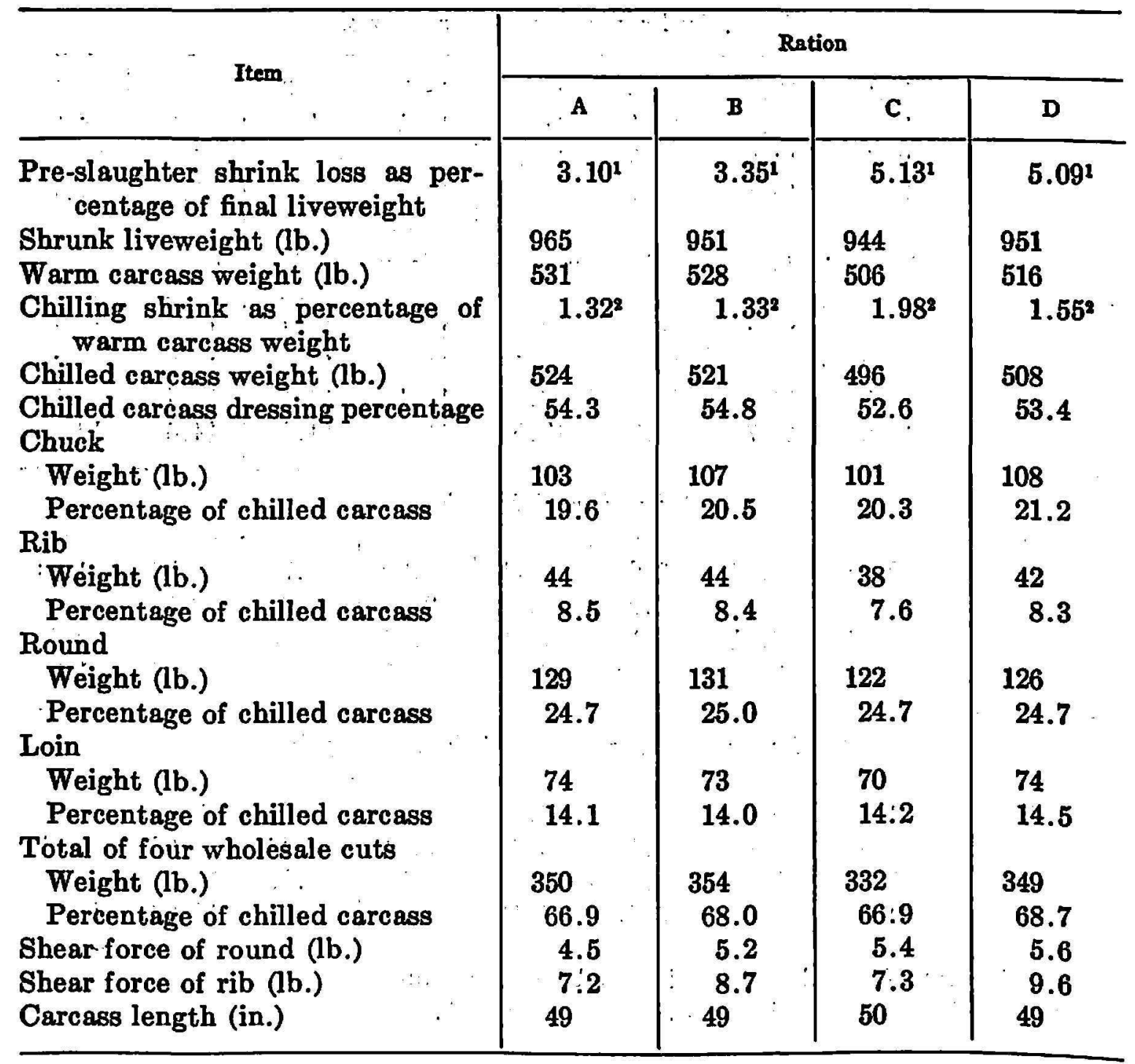

$\therefore$ There was a highly significant difference $(P<.01)$ between the combined average of rations $A$ and $B$ us. that of rations $C$ and $D$.

There was a significant difference $(P<.05)$ between the combined average of rations $A$ and $B$ vs. that of rations $C$ and $D$.

which would result in greater shrink losses. The average shrunk liveweights ranged from 944 to 965 pounds among the 4 groups (table 4 ).

At slaughter the weight of the viscera and their contents was 25.1, 24.0, 26.8, and 25.3 percent of the shrunk liveweight of the animals which had consumed rations $\mathrm{A}$ through $\mathrm{D}$, respectively. The tendency toward greater visceral weights in the animals fed the rations higher in bagasse content 
was not significant. A close examination was made of the entire digestive tract of 10 of the animals killed in this experiment. All were in excellent condition and showed no signs of gross lesions.

The slight variation among rations in weight of the liver as a percentage of shrunk liveweight was not significant; the average figures were 1.3, 1.2, 1.4, and 1.3 for rations $A$ through $D$, respectively. No gross lesions of the liver were observed.

The respective average percentages of the shrunk liveweight represented by several other parts of the body for diets $A$ through $D$, were: Hide, 8.4, 8.5, 8.4, and 8.5; head, 3.6, 3.5, 3.6, and 3.8; and feet, 2.0, 2.0, 2.3, and 2.2. The only significant difference among treatments occurred in the case of percentage of shrunk weight represented by the feet, which was greater $(P<.05)$ for the diets with higher bagasse content. The latter result has no apparent logical explanation and is probably fortuitous.

Average warm carcass weights ranged from 506 to 531 pounds among the 4 groups (table 4). Upon chilling, the carcasses from the animals fed diets A through $D$ lost an average of 1.32, 1.33, 1.98, and 1.55 percent of their initial weights, respectively (table 4). The loss was greater $(P<.05)$ for diets $\mathrm{C}+\mathrm{D}$ than for diets $\mathrm{A}+\mathrm{B}$. The fact that the carcasses of the animals fed diets with higher bagasse content lost proportionately more weight upon chilling is another result difficult to explain. Average chilled carcass weights ranged among treatments from 496 to 524 pounds (table 4). Chilled carcass dressing percentages averaged 54.3, 54.8, 52.6, and 53.4 for diets $\mathrm{A}$ through $\mathrm{D}$, respectively. The advantage in dressing percentage in favor of the diets of lower bagasse content was not significant. A higher average dressing percentage of 58.6 was reported by Cole et al. (B) for Holstein and Jersey steers which were killed at approximately 20 months of age and 850 pounds shrunk liveweight.

The average percentages of the chilled carcass weight represented by various wholesale cuts ranged among treatments as follows: Chuck, 19.6 to 21.2 ; rib, 7.6 to 8.5 ; round, 24.7 to 25.0 ; and loin, 14.0 to 14.5 (table 4). The sum of the four wholesale cuts represented 66.9, 68.0,66.9 and 68.7 percent of the chilled carcasses obtained from the animals fed diets A through $D$, respectively. No significant effect of the diets on carcass yield of wholesale cuts was found. Variation among treatments in average carcass length was practically nil (table 4).

The meat obtained from the animals in this experiment was of excellent quality. The average shear force determined on samples of round varied among treatments from 4.5 to 5.6 pounds and that determined on samples of rib varied from 7.2 to 9.6 pounds (table 4). The diets had no significant effect on this criterion for meat tenderness.

The data were subjected to " $t$ " tests to determine whether the breed of 
the animals or their castration status affected two of the most important response criteria, viz, daily liveweight gain and carcass dressing percentage. The Holstein and Brown Swiss averaged 2.50 and 2.59 pounds in the former criterion and 54.3 and 55.3 percent in the latter, respectively. In neither case was the small difference between breeds significant. The intact animals gained liveweight more rapidly than the castrates (2.65 vs. 2.37 pounds per day), but the difference was not significant. In carcass dressing percentage, however, there was a significant $(P<.01)$ advantage in favor of the intact animals (54.9 vs. 52.3). The poorer average responses of the castrates are not surprising because these animals received no hormonal treatment.

\section{SUMMARY AND CONCLUSIONS}

Sixteen Holstein-Friesian and Brown Swiss male calves, ranging in age from 212 to 278 days and in weight from 162 to 339 pounds, were fed to slaughter weights of approximately 1,000 pounds on four mixtures of sugarcane bagasse and concentrates. All four mixtures were fed ad libitum as the sole diet to two pairs of animals in two separate pens. The diets contained two levels of bagasse (20 and 30 percent) and two levels of crude protein (approximately 12.5 and 16 percent), thus constituting a $2 \times 2$ factorial design.

The following respective average responses were observed on diets $A$ (low bagasse-low protein), B (low bagasse-high protein), C (high bagasselow protein), and D (high bagasse-high protein): Daily liveweight gain, $2.46,2.61,2.54$, and 2.33 pounds; daily feed consumption, 19.3, 19.0, 20.5, and 19.7 pounds; and feed consumed per pound of gain, 7.84, 7.28, 8.07, and 8.45 pounds. None of these differences among treatments were significant. The feed conversion ratios were in the range of 4.5 to 5.5 during the first month and thereafter increased steadily to values approaching and/or above 10.0 .

During the 24-hour pre-slaughter shrink the animals fed the high-bagasse diets lost proportionately more liveweight than the animals fed the lowbagasse rations (5.13 and 5.09 vs. 3.10 and 3.35 percent). The same result was found as to weight lost by the carcass upon chilling (1.98 and $1.55 v s$. 1.32 and 1.33 percent).

The diets had no significant effects on chilled carcass dressing percentages, the averages being $54.3,54.8,52.6$, and 53.4 for A through $D$, respectively. Neither were there any significant differences among treatments in the percentages of chilled carcass weight represented by the various wholesale cuts nor in the Warner-Bratzler shear force-scores of meat samples from the rib or round. It is concluded that all four formulas gave excellent and comparable results in growth response of the animals and their carcass 
yields. The higher level of protein was not significantly beneficial, nor the higher level of bagasse significantly detrimental.

\section{RESUMEN Y CONCLUSIONES}

Se alimentaron 16 becerros de las razas Holstein-Friesian y Suiza Parda, de una edad inicial que fluctuaba entre 212 y 278 días y un peso vivo inicial de entre 162 y 339 libras, exclusivamente con 4 mezclas de bagazo de caña de azúcar y alimentos concentrados, hasta un peso de matanza de aproximadamente 1,000 libras. Se suplió a discreción una de las 4 mezclas como ración única, a 2 pares de animales alojados en 2 corrales separados. Las fórmulas contenían 2 niveles de bagazo ( 20 y 30 por ciento) y 2 niveles de proteína bruta (aproximadamente 12.5 y 16 por ciento), lo cual constituía un diseño factorial de $2 \times 2$.

Los animales alimentados con las dietas A (baja en bagazo y en proteína), B (baja en bagazo y alta en proteína), $\mathbf{C}$ (alta en bagazo y baja en proteína), y D (alta en bagazo y en proteína) tuvieron los siguientes promedios respectivos: Ganancia diaria en peso vivo, 2.46, 2.61, 2.54 y 2.33 libras; consumo diario de alimento, 19.3, 19.0, 20.5, y 19.7 libras; y alimento consumido por libra de aumento de peso vivo, 7.84, 7.28, 8.07 y 8.45 libras. Ninguna de estas diferencias entre los tratamientos fue significativa estadísticamente. Durante el primer mes experimental los animales consumieron un promedio de 4.5 a 5.5 libras de alimento por libra de aumento, aumentando después dicha razón hasta aproximarse y/o sobrepasar las 10 libras.

La pérdida de peso vivo durante las 24 horas de enchiqueramiento o ayuno, antes de la matanza, fue proporcionalmente mayor entre los animales que consumieron las dietas altas en bagazo que entre los que consumieron las dietas bajas en bagazo (5.13 y 5.09 contra 3.10 y 3.35 por ciento). Asimismo fue la pérdida en peso por la canal al enfriarse (1.98 y 1.55 contra 1.32 y 1.33 por ciento).

Los promedios de rendimiento de la canal enfriada fueron $54.3,54.8,52.6$ y 53.4 por ciento con las raciones $\mathrm{A}, \mathrm{B}, \mathrm{C}$ y $\mathrm{D}$, respectivamente, sin que las diferencias fuesen significativas. Tampoco hubo diferencias significativas entre los tratamientos en cuanto a los porcentajes de la canal enfriada, representados por los varios cortes para la venta al por mayor, ni en los valores Warner Bratzler basados en la fuerza necesaria para cortar muestras de carne de cadera o de costilla. Se concluye que las 4 raciones dieron resultados excelentes y comparables en cuanto al crecimiento de los animales y al rendimiento de sus canales. El nivel más alto de proteína no mejoró significativamente los resultados, ni el más alto nivel de bagazo los empeoró significativamente. 


\section{LITERATURE CITED}

1. Anonymous, Profitable Meat Cutting, Successful Meat Merchandising and SelfService Meats, 2nd rev., nos. 1-4, National School of Meat Cutting, Toledo, O., 1960.

2. Beames, R. M., Bagomolasses as the basis of a fattening ration for cattle, Queensland J. Agr. Sci. 18: 425-36, 1961.

3. Cole, J. W., Rasey, C. B., and Hobbs, C. S., Effects of type and breed of British, Zebu, and dairy cattle on production, carcass composition and palatability, J. Dairy Sci. 47: 1138-44, 1964.

4. Kirk, W. G., Peacock, F. M., and Davis, G. K., Utilizing bagasse in cattle fattening rations, Bull. 641, Fla. Agr. Exp. Sta., 1962.

5. Kleiber, M., Metabolic body size, In Proceedings of the 3rd. Symposium on Energy Metabolism, Troon, Scotland, Academic Press, New York, N.Y. pp. 427-35, 1965.

6. Natl. Acad. Sci.-Natl. Res. Council, Nutrient requirements of domestic animals IV, Nutrient requirements of beef cattle, Publ. 579, 1958.

7. Sharrah, N., Kunze, M. S., and Pangborn, R. M., Beef tenderness: Comparison of sensory methods with the Warner-Bratzler and L. E. E.-Kramer shear presses, Food Technol. 19: 136-43, 1965. 